一論 文—

（日本化学会誌，1996，（2）， p. 166～175）

(C) 1996 The Chemical Society of Japan

\title{
コンニャクグルコマンナンを分子ふるい添加物とする キャピラリー電気泳動法による生体高分子の分離
}

(1995 年 10 月 25 日受理)

山口正人*·泉友則圢・礒辺俊明 + 奥山典生 ${ }^{\dagger \dagger}$

天然の高分子多糖であるグルコマンナン $(\mathrm{GM})$ およびスラブ電気泳動の支持体として用いられてい る市販の試薬を含むいくつかの多糖類を, キャピラリー電気泳動 $(\mathrm{CE})$ 用ポリマー溶夜として，それら の分子ふるい添加物としての高分子分離特性について比較, 検討した. その結果, 溶液濃度および測定 条件を統一し，分離対象物質として制限酵素消化 DNA フラグメントを用いた場合，GM が最も高い分 離度を示した．これは GM が他の多糖類と比較して分子量が大きいこと，分岐の少ない直鎖状の構造 を持ち慣性半径が大きいことなどにより, キャピラリ一内で安定な網目を形成するためと考えた。一般 に DNA フラグメントの分離度は，GM 濃度を調整することで改善が可能であった．しかし，オリゴヌ クレオチドのような低分子試料，また数千 bp といったかなり大きな DNA フラグメントの分離には， $\mathrm{GM}$ 濃度の調整だけでは十分には対応できないことがわかった．この場合，GM の分子量が分離度に大 きく影響しており，分離対象物質の分子量に応じて，分離媒体である GM の分子量を適切に選択する ことが重要であることがわかった．また，分離度以外に GM 溶液は，(1)毒性がない，(2)長期保存安定 性にすぐれている，(3)分析の再現性が良好であり自動化がはかれる，といった CE 用ポリマー溶液とし て好をしい特徵をいくつか持っていることが確認できた.

本研究の成果は, 将来 PCR 産物の分析, 遺伝子解析など生命科学領域への適用が可能であると考え る.

\section{1 緒 言}

生命科学領域における分析技術の発展は, 生体物質の化学構造 や立体構造の解析, また物理化学的性質や生体機能との関連の解 明に大きく寄与しており，さらなる高分解能分析法や高感度分析 法の開発，あるいは分析法の自動化や高速化が望まれている。近 年, 迅速 ·簡便 ·高感度 ·高分離な分析手段として, キャピラリ 一電気泳動法 (Capillary Electrophoresis, 以下 CE と略す) が注 目されており，さまさまな研究分野の発展に貢献しつつある. と りわけ，遺伝子工学など生命科学領域においては，ヒトゲノム解 析に代表されるようにDNA の高性能自動化分析への適用が期待 されている12).これまで CEによるDNAの分離は, ポリアク リルアミドなどをキャピラリー内でゲル化もしくは化学結合させ た，いわゆるキャピラリーゲル電気泳動法3) 5) (以下 CGE と略

栗田工業株式会社総合研究所, 243-01 厚木市森の里若 宮 7-1

†東京都立大学理学部化学科生物化学教室, 192-03 八王 子市南大沢 1-1

\#現在 山形大学医学部分子病態学講座, 990-23 山形市 飯田西 2-2-2

而現在 神奈川歯科大学歯科生体工学教室, 238 横須賀市 稲岡町 82
す）と主に線状高分子を緩衝液に溶解させた，ポリマー溶液と呼 ばれるものを利用した方法6) 8)が一般的に用いられてきた。特 に，ポリマー溶液を用いる方法はゲルを用いる方法に比べて，(1) 調製が簡単であり熟練を要しない，(2)溶液交換によりキャピラリ 一の繰り返し使用が可能でありゲル充填キャピラリーに見られる ような劣化の心配がない，(3)再現性が良く自動化に適している， といった利点がある.このような簡便さは，分析法の実用性とい う観点から非常に重要であり, また CE の普及という点でも大切 と考えられる. そのため，ここ数年ポリマー溶液を用いる $\mathrm{CE}$ が， CGEに代わって盛んに研究されるようになってきている910).

著者らはこれまで食品分野以外ではほとんど利用されていなか った天然の高分子多糖であるコンニャク (Amorphophallus kon$j a c)$ 由来グルコマンナンを, 高速液体クロマトグラフィー(以下 HPLC と略す) 用充填剤に適用する研究を行い, 従来のアガロ 一ス，デキストランなどからなるソフトゲルに対し，マクロ細孔 を有しながら数倍の物理的強度を持つハードゲルが調製できるこ とを見いたした ${ }^{11) ~ 13)}$.さらに, HPLC 用充填剤以外の適用分野 として電気泳動用ゲルが有望と考え，検討を行ってきた，その結 果, 特に CE 用分子ふるい添加物ポリマーとして好ましい性質を 持っていることが，最近明らかになった ${ }^{14) 15) .}$

本研究では, グルコースとマンノースを主成分とするコンニャ 
クグルコマンナンとガラクトースなどを主成分とする他の多糖類 を用いて，CE 用分子ふるい添加物ポリマーとしての適性を調ぺ ることを主な目的とし，その分離特性について比較，検討したの で報告する.

\section{2 実 験}

\section{1 装置}

$\mathrm{CE}$ 装置はアプライドバイオシステムズ社製 Model $270 \mathrm{~A}$ も くは日本分光工業製 CE-800 (高圧電源 890-CE, UV 検出器 Model 875-CE) を用いた. キャピラリーは J \& W サイエンテ イフィック社製 DB-WAX (100 $\mu \mathrm{m}$ I.D., $375 \mu \mathrm{m}$ O.D.) を全長 $50 \sim 100 \mathrm{~cm}$, 検出器までの長さ $20 \sim 80 \mathrm{~cm}$ で使用した.

\section{2 試菜}

2-アミノ-2-ヒドロキシメチル-1,3-プロパンジオール(以下ト リスと略す), 塩酸, エチレンジアミン四酢酸二ナトリウム(ED$\mathrm{TA} \cdot 2 \mathrm{Na})$, リン酸一水素ナトリウム, ホウ酸など緩衝液の調製 に必要な試薬は市販の生化学用もしくは特級を用いた. DNA 試 料として, $\Phi \times$ 174/Hae III, $\lambda \mathrm{DNA} /$ Hin d III, $\Phi$ x 174RFI/Hin f I の各制限酵素消化フラグメントはニッポンジーンより，またデ オキシアデニル酸 40-60 量体混合物 $\left(\mathrm{p}(\mathrm{dA})_{40-60}\right)$ およびデオ キシチミジル酸 15 量体 $\left(\mathrm{p}(\mathrm{dT})_{15}\right)$ は, ファルマシアバイオテク よりそれぞれ購入した. CE 用ポリマー溶液の調製に必要な多糖 類としてヒドロキシプロピルメチルセルロース(HPMC : 4000 cps $/ 2 \%$, Sigma 製)，デキストラン( $M_{\mathrm{W}} 2000 \mathrm{~K}$, Sigma 製 $)$ ，プ ルラン $\left(M_{\mathrm{W}} 50 \sim 100 \mathrm{~K}\right.$, 和光純薬工業製), アガロース(商品名 : H14 TAKARA，宝酒造製，商品名: Nu Sieve ${ }^{\circledR}$ 3:1 Agarose, $\mathrm{FMC}$ 製), ガラクトマンナン $\left(M_{\mathrm{W}} \sim 200 \mathrm{~K}\right.$, Ceratonia siliqua 由 来, Fluka 製）を用いた.

\section{3 グルコマンナンの精製}

分子量の異なるグルコマンナン(コンニャク粉）は清水化学が 食品用として製造, 販売しているものを購入して用いた.このグ ルコマンナンを蒸留水に一晚溶解させ， $5 \%$ 水溶液を調製した. 次に, 1.3 倍容量のエタノール中に徐々にかき混ぜながら沈殿さ せた． その後，400メッシュのふるいで固液分離を行い，沈殿物 を速やかにエタノールに浸して脱水した。 さらに, 乾燥空気雾囲 気で一晚乾燥し, 精製グルコマンナンを得た。 また, 分子量の測 定は光散乱法およびサイズ排除クロマトグラフィーによって行っ た.

\section{4 低分子グルコマンナンの調製}

食品用グルコマンナンの分子量は通常 100 万以上であるため, 数十万の分子量を持つグルコマンナンは, 若い種芋である生子 （きご）から抽出し，調製した，精製方法および分子量の測定は， 上記 2.3に従った.

\section{5 グルコマンナンの酵素分解による低分子化}

未精製のグルコマンナン（分子量 130 万） $2 \mathrm{~g}$ を $1 l$ のリン酸緩 衝液 (100 mM, pH 7) に溶解後, Bacillus sp. の培養液から精製 した分解酵素 $100 \mathrm{mg}$ を添加し，室温で 24 時間放置した．次に， 反応液の 5 倍体積のエタノールをかきまぜながら加え, 低分子 化グルコマンナンを析出させると共に, 分解酵素を失活させた. その後, $15000 \mathrm{rpm}$ で 10 分間遠心分離を行い, 析出物を回収し た. 再度エタノールで洗浄, 脱水を行い, 真空㲦燥した.ここで 得られたグルコマンナンの平均分子量は $2.7 \sim 5.4$ 万の範囲であ
った.

\section{$2.6 C E$ 用ポリマー溶液の調製}

精製グルコマンナンを含めて，各多糖は所定量を CE 用緩衝液 に溶解させた。 その後, $15000 \mathrm{rpm} て ゙ 1$ 時間遠心分離を行い, 不溶物を除去し，CE 用ポリマー溶液として用いた。なお，市販 の各多糖については, 特に遠心分離以外の前処理は行わなかっ た. また，遠心分離で除去される不純物はごくわずかであり，濃 度補正は行わなかった. オートクレーブなどの隇菌処理は, 処理 後一部の多糖で変色, 変質が確認されたため実施しなかった.

\section{7 電気泳動用試料の調製}

デオキシアデニル酸 40-60 量体混合物 $\left(\mathrm{p}(\mathrm{dA})_{40-60}\right)$ および デオキシチミシル酸 15 量体 $\left(\mathrm{p}(\mathrm{dT})_{15}\right)$ は, 蒸留水に溶解し, そ れぞれ0.5, $0.06 \mathrm{U} / \mathrm{m} l$ として使用した。この場合 $10 \mathrm{~mm}$ セルを 用いた $260 \mathrm{~nm}$ における吸光度 $1.0 を 1.0 \mathrm{U} / \mathrm{ml}$ とした. 市販の DNA フラグメントは保存状態のものを, そのまま使用した.

\section{8 キャピラリー電気泳動}

泳動用緩衝液として，トリスー塩酸/EDTA 系を用いた. 分析 ごとにポリマー溶をガラスシリンジを用いてキャピラリー内に 圧入もしくは自動吸引による注入を行った後, 陰極側より電圧を 掛けて数秒間試料を導入し, 定電圧で泳動を行った.

\section{3 結果および考察}

\section{1 グルコマンナンの精製}

食品用として肘売されている粗製グルコマンナン(コンニャク 粉）をそのまま CE 用ポリマー溶液として使用した場合, ベース ラインの安定性に欠け, 小さなピークの同定ができなかった.こ れは主に, グルコマンナンに僅かに含まれるタンパク質, 脂質, 灰分などの不純物の影響であることがわかった。エタノール沈 殿，遠心分離による精製は不純物の除去に効果的であった. 精製 前と後の IR およびUV 吸収スペクトルを測定した結果, 不純物 に起因すると思われる吸収帯が減少した．特に，UV 吸収スペク トルでは核酸・タンパク質に起因すると思われる260～280 nm 付近の吸収帯の減少が顕著に確認できた. 精製が十分であれば, 泳動時のエレクトロフェログラムのベースラインの乱れ, 電流値 の増大，気泡およびゴーストピークの発生などは認められなかっ た.

\section{2 緩街液条件の検討}

トリスーホウ酸,トリスー塩酸、リン酸をそれそれ70 mM, pH 8.2 に調整後 $14 \mathrm{mM}$ EDTA を添加した緩衝液に多糖類を溶解し, DNA フラグメントの分離に及ぼす影響を検討した．今回検討し た緩衝液ではトリスー塩酸が最も分離が良く，またトリスーホウ 酸が最も悪かった. 緩衝液の濃度は, 泳動時の電流值から判断し て70 mM くらいが適切であり，これ以上濃度を高くしても分離 度が改善されることはなかった。トリスーホウ酸緩衝夜で DNA フラグメントの分離が一部不完全であるのは, 糖の構造や物性の 変化と関係があるのではないかと考えられる. たとえばブルラン は，他の多糖類と比較して，粘度が低いことがわかっている．し かし, ホウ素の混在により粘度が影著に高くなることが報告され ている ${ }^{16)}$. したがって, 糖の構造や物性の変化と分離度には密 接な関係があることは十分予測されるが，今回これ以上詳細な検 討は行わなかった. 


\section{3 調製後のポリマー溶液の安定性}

今回用いた多糖の多くは，ポリマー溶液として調製後隇菌処理 を行わず室内で密封保存した場合，1 か月以内に沈殿物の析出や 変色などが認められた. しかし，グルコマンナンの場合は，6か 月以上経過しても外観に変化は認められなかった。 また, 分離性 能もほとんど変化は認められなかった.一般的な環境下では他の 多糖より生分解や加水分解を受けにくいと推察される。一度調製 したポリマー溶夜が, 室内で長い期間安定であることは, ルーチ ン分析や自動分析を行う上で大切なことであり, CE 用ポリマー 溶液の素材に求められる不可欠な条件の一つと言える.

一方, 酵素による分解を行った低分子化グルコマンナン溶液は, 1 週間程度で白濁が認められた。これは今回検討した精製方法で は，酵素を完全に失活させることができなかったためと推察され る. その結果, 保存時に低分子化反応が進行し, 変質につながっ たと考えられる. 酵素反応後の精製方法の改善が今後の課題と言 える.

\section{4 泳動時の温度の影響}

カラムオーブンで泳動時の温度を検討した結果, 温度が高くな るにつれて各 DNA フラグメントの分離度は低下した．これは， 今回用いたすべての多糖について認められた. どの多糖も温度の 上昇と共に粘度が低下することから，キャピラリ一内で安定な網 目が形成されにくくなるためと考えられる，したがって，今回の 温度条件は室温 $\left(20^{\circ} \mathrm{C}\right)$ で統一することにした.

\section{5 各ポリマー溶液の分離性能の比較}

各多糖を $0.25 \%$ のポリマー溶液として調製し, DNA フラグメ ントの分離性能を比較した. DNA フラグメントの分子量と移動

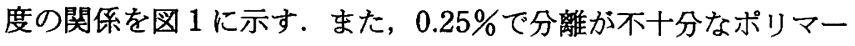
溶液については, 試料の移動時間が $0.25 \%$ グルコマンナンの時 とほほ同じになるよう濃度を高め, 分離度の改善をはかった. な

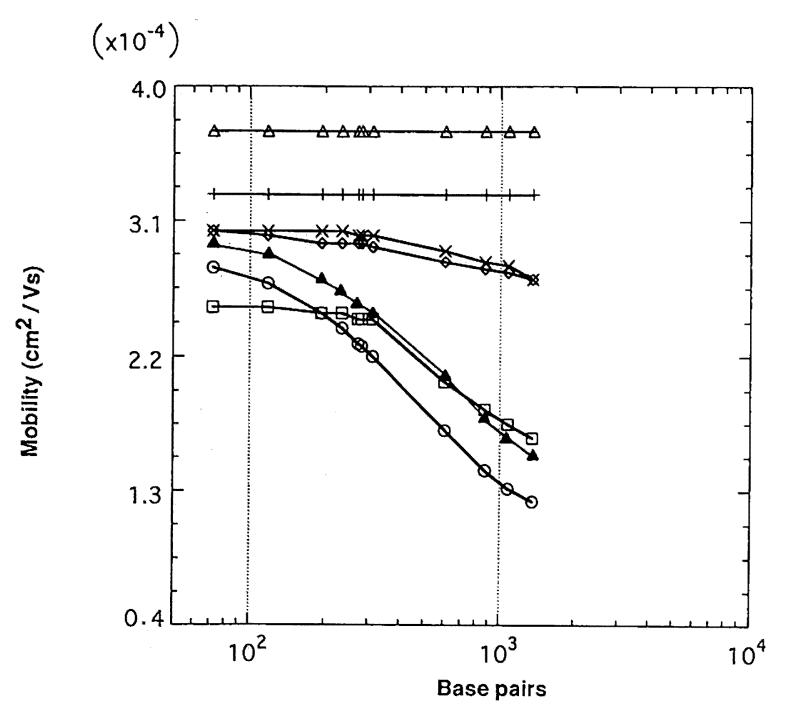

Fig. 1 Relationship between mobility and size of restriction DNA fragments.

Logarithm of mobility of restriction DNA fragments is plotted against size of them.

(O) Glucomannan, ( $\boldsymbol{\Delta}$ ) Galactmannan, ( $\square$ ) HPMC,

$(\diamond) \mathrm{Nu}$ Sieve ${ }^{\circledast}$ : 1 Agarose, $(x)$ H14 TAKARA,

$(+)$ Dextran, $(\triangle)$ Pullulan.

Conditions

Capillary: J \& W DB-WAX $100 \mu$ m I.D. $\times 50 \mathrm{~cm} /$ effective length $20 \mathrm{~cm}, 0.25 \%$ polysaccharides in $70 \mathrm{mM}$ Injection: $5 \mathrm{kV} 1 \mathrm{~s}$ Tris- $\mathrm{HCl}$ (pH 8.2), 14 mM EDTA.

Run: $5 \mathrm{kV}$

Detection: $260 \mathrm{~nm}$

Sample: Hae III digest of $\Phi \times 174$ DNA, $0.47 \mathrm{mg} / \mathrm{ml}$ Instrument: JASCO CE-800
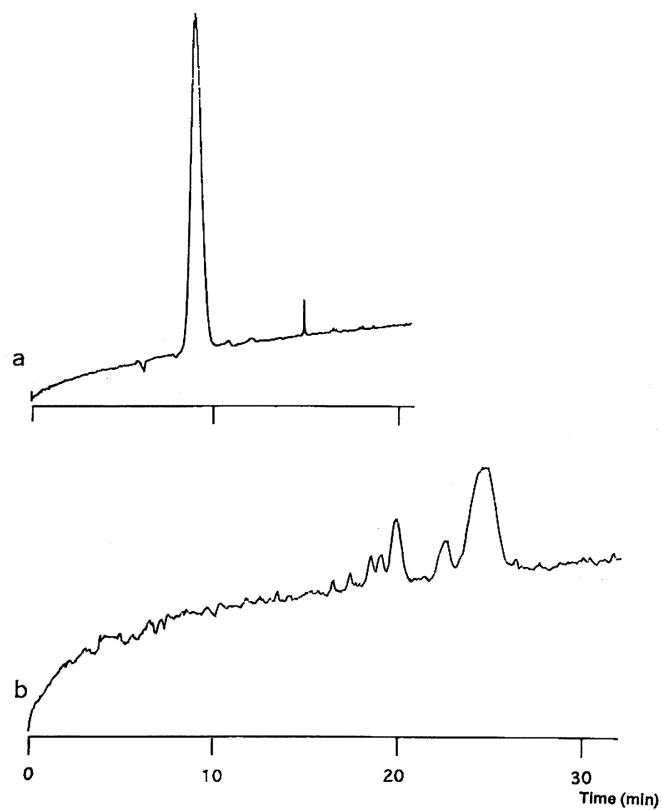
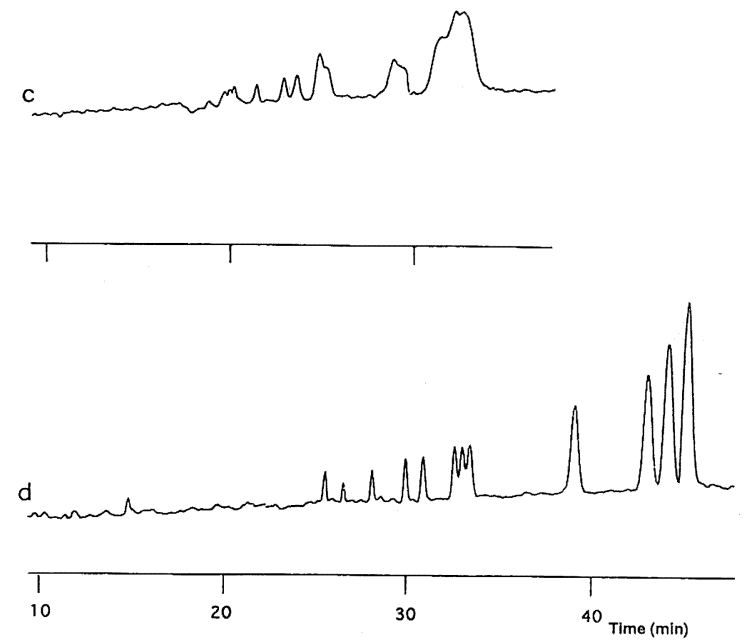

Fig. 2 Separation of restriction DNA fragments using pullulan. (a) $0.25 \%(w / w)$, (b) $5 \%$, (c) $7 \%$,(d) $10 \%$.

Conditions

Capillary: Pullulan $\left(M_{\mathrm{W}} 50 \sim 100 \mathrm{~K}\right.$ ) in $70 \mathrm{mM}$ Tris- $\mathrm{HCl}$ (pH 8.2), $14 \mathrm{mM}$ EDTA.

All other conditions as in Fig. 1. 
お，ポリマー溶液によっては，粘度の高さから必ずしも移動時間 を同じにできないことがあった，その場合は，キャピラリーに注 入できる限界をで濃度を高めて検討した. キャピラリーは分離度 の差が明確になるよう, 検出器までの有効長を $20 \mathrm{~cm}$ と短くし た. また，グルコマンナンは今回 $2.7 〜 200$ 万の分子量のものを 用意したが，ここでは最も食品用として入手し易い 130 万のもの を用いた。

デキストランの場合， $0.25 \%$ では DNA フラグメントは全く分 離しなかった．この濃度では，網目が形成されにくいと考えられ る. 20 倍高濃度の $5 \%$ にした場合でも, 各フラグメントの分離 は十分ではなく, 特に分子量の大きいフラグメントで分離は悪か った. アガロース(H14 TAKARA) では，0.8\%に濃度を高めて も, 各フラグメントピークの分離は余り改善されなかった. 一方, Nu Sieve ${ }^{\oplus}$ : 1 Agarose では, 0.25\%で不十分であったフラグメ ントピークの分離が，0.8２\%の濃度ではかなり改善すること がわかった。これはアガロース(H14 TAKARA) の結果から判 断して主成分のポリマーである $\mathrm{Nu} \mathrm{Sieve}$ の分離効果と考えら れる. また, 濃度が高くなるにしたがってべースラインの変動が 大きくなったのは，製品中に含まれる夾雑物の濃度が高まった影 響と推察される.

HPMC では， $0.25 \%$ か $0.5 \%$ に濃度を高めても大きなフラグ メントの分離が少し改善されただけであり，小さなフラグメント は分離が不十分のままであった．プルラン(図 2) では，粘度が 他の多糖より低いため, 10\%までキャピラリー内に注入するこ とが可能であった． $0.25 \%, 5 \%(\mathrm{a}, \mathrm{b})$ の分離パターンはデキス トランの場合とかなり類似していた７\%(c)では小さなフラグメ ントピークの分離が改善され，10\%(d)では大きなフラグメント も十分に分離させることが可能であった．これは濃度が高くなる にしたがって，プルランの鎖が分子間で絡み合ってより安定な網 目が形成されるためと考えられる.

ガラクトマンナンおよびグルコマンナン（図 3) では，共に $0.25 \%$ で各 DNA フラグメントの相互分離が可能であった．厳密 な比較では，ガラクトマンナンがグルコマンナンより大きなフラ

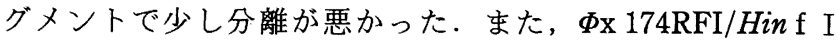
（16フラグメント ; 24～726 base pairs : 以下 bp と略す）のよう

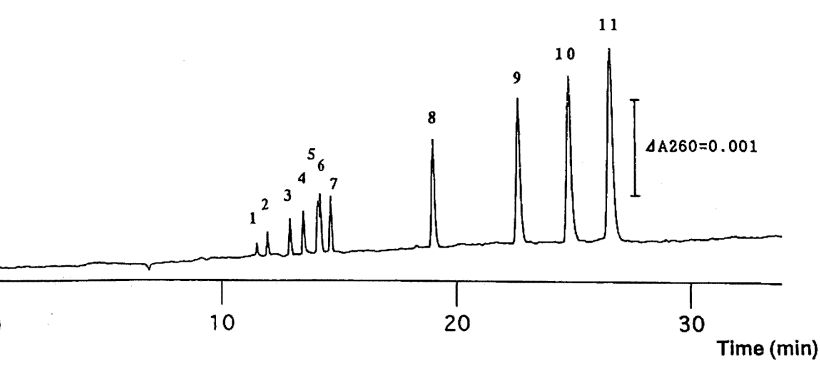

Fig. 3 Separation of restriction DNA fragments using glucomannan.

Peaks: $1=72, \quad 2=118, \quad 3=194, \quad 4=234, \quad 5=271$, $6=281,7=310,8=603,9=872,10=1078,11=1353$ bp.

Conditions

Capillary: $0.25 \%(\mathrm{w} / \mathrm{w})$ glucomannan $\left(M_{\mathrm{W}} 1300 \mathrm{~K}\right)$ in 70 mM Tris- $\mathrm{HCl}$ (pH 8.2), 14 mM EDTA.

All other conditions as in Fig. 1.
に分子量が近接している試料では，ガラクトマンナンと比較して グルコマンナンの分離度の高さがより明確であった.

以上, 今回用いた多糖類の中では，グルコマンナンが最も分離 度が高かった。 また，スラブゲル電気泳動の支持体として使用さ れているガラクトースを主成分とする試薬が，必ずしむ CE 用ポ リマー溶液に適用できるとは限らないことが明らかになった。グ ルコマンナンの分離度が高かった理由として，分岐の少ない直鎖 状の構造を持つこと，また，分子量が大きく慣性半径二乗平均 $\left.\left(<S^{2}\right\rangle^{1 / 2}\right)$ が大きいことにより，マトリックスが密で強固な網 目を形成するためと考えられる，たとえば，分子量 100～200 万 前後のグルコマンナンの慣性半径は, 約 100～230 nm になるこ とが報告されている ${ }^{17)}$. HPLCなどの分子量マ一カーとして用い られるプルラン（分子量 250 万）の慣性半径が約 $75 \mathrm{~nm}$ であるこ と䄈を考えると, グルコマンナンの慣性半径はかなり大きいと 言える. しかし, 今回用いた多糖類の各濃度における慣性半径に ついては実測しておらず，分離度との関係を明らかにすることが 今後の検討課題と考えられる.

\section{6 グルコマンナンのポリマー溶液としての分離機構}

濃度および分子量の異なるグルコマンナン溶液および DNA フ ラグメントを用いて, 分離機構について考察した。

3.6 .1 溶液濃度と分離度の関係: 分子量 130 万のグルコマン ナンを用いて, 溶液濃度が分離に与える影響について検討した。

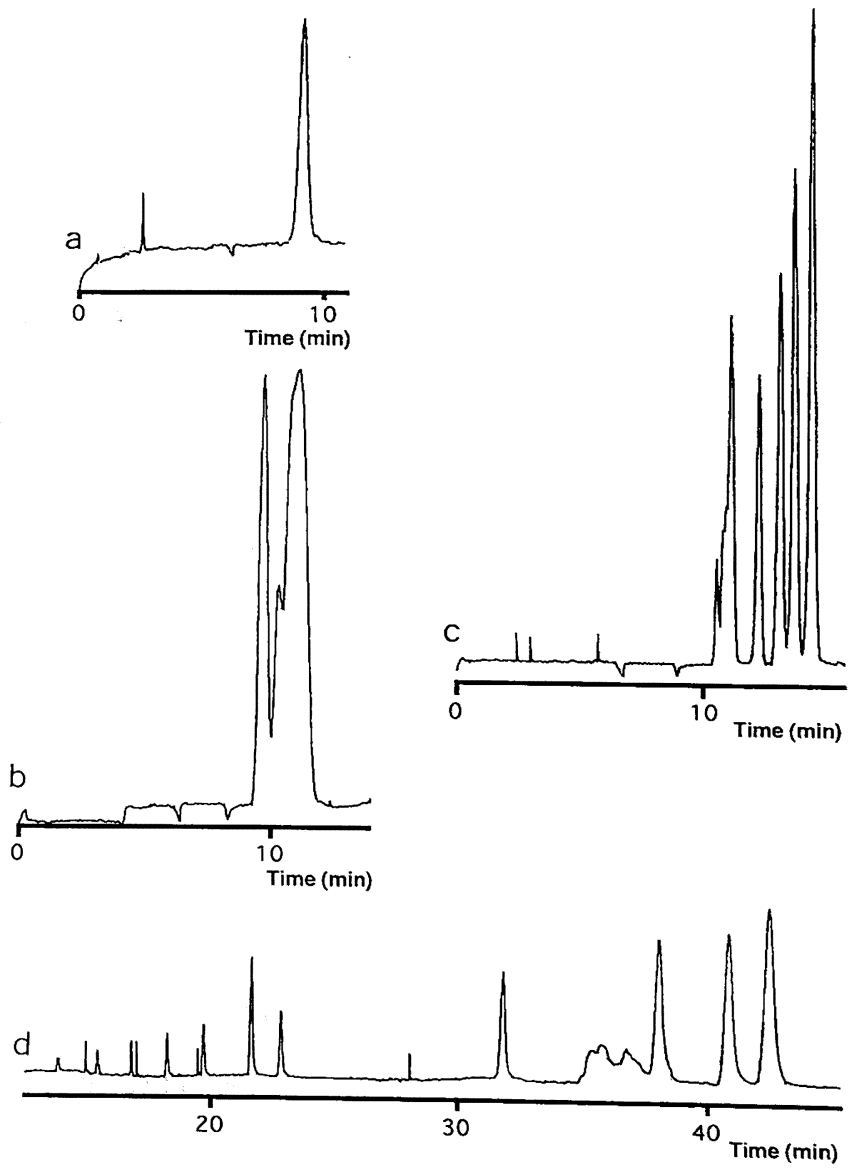

Fig. 4 Effect of concentration of glucomannan on separation of restriction DNA fragments. (a) $0 \%(w / w),(b)$ $0.05 \%$, (c) $0.1 \%$, (d) $0.7 \%$.

All other conditions as in Fig. 1. 
エレクトロフェログラムを図 4 に示す.

0\%(a)では大きな 1 本のピークたけであったエレクトロフェロ グラムが, $0.05 \%(b) て ゙ は ~ 2$ 本に分離しているのがわかる. 最初の ピークは小さなフラグメントの集まりであり， 2 番目のピークは 大きなフラグメントの集まりと考えられる．2 番目のピークで肩 のように見えるむのは分離途中の中間の大きさのフラグメントと 推察される．これは，0.05\%という非常に希薄な濃度であって む, グルコマンナンの鎖が絡み始めて網目を形成しつつある現象 と考えられる.

$0.1 \%(\mathrm{c})$ では大きなフラグメントの分離はかなり改善されてお り、キャピラリー内ですでに大きな網目が形成されていると思わ れる. $0.25 \%$ では前記図 3 のように各フラグメントの相互分離が 可能であった，さらに0.7\%(d)まで濃度を高めると，小さなフラ グメントの分離度は一層改善されたが, 逆に大きなフラグメント ではピークがブロードになり分離度の低下が認められた．基本的 に小さなフラグメントの分離度は, 高分子量のグルコマンナン溶 液の濃度を高めることで改善がはかれると考えられる.しかし， $\mathrm{CE}$ で用いられるキャピラリーの一般的な内径が $100 \mu \mathrm{m}$ 以下で あることを考えると, 高濃度の溶液はその粘度の高さからキャピ ラリ一内への注入は困難になり，実用性に問題があると言える.

次に，各濃度における DNA フラグメントの分子量と移動度の 関係を図 5 に示す．濃度が高まるにしたがって，特に大きなフ ラグメントの移動度が小さくなっているのがわかる．また図 6 にグルコマンナン溶液の濃度と三つの分子量範囲に分けた DNA フラグメントの分離度の関係を示す.この場合, 最も分離が良か った濃度での分離度を 1 として，相対分離度 (Relative Resolution : $R_{\mathrm{r}}$ ) で比較してある. 図から明らかなように, $72 \sim 118 \mathrm{bp}$ の小さな分子量のフラグメントと $310 \sim 603 \mathrm{bp}$ の中間の分子量を

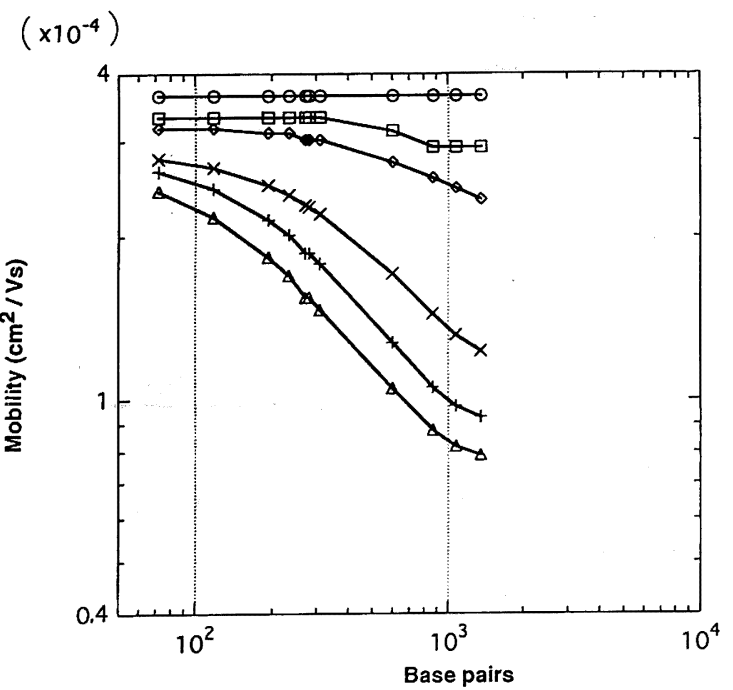

Fig. 5 Effect of concentration of glucomannan on mobility of restriction DNA fragments.

Results in Fig. 4 and additional data with two diffrent concentration $(0.25 \%$ in Fig. 3 and $0.5 \%)$ are summarized.

Logarithm of mobility of restriction DNA fragments is plotted against size of them.

( $\bigcirc) 0 \%(\mathrm{w} / \mathrm{w}),(\square) 0.05 \%,(\diamond) 0.1 \%,(\times) 0.25 \%$, (+) $0.5 \%,(\triangle) 0.7 \%$.

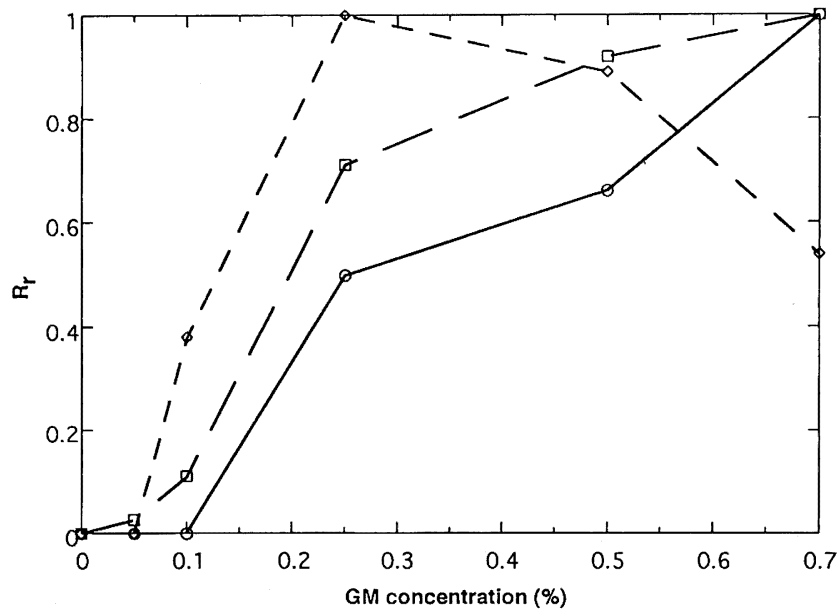

Fig. 6 Effect of concentration of glucomannan (GM) on resolution of restriction DNA fragments.

Relative resolution $\left(R_{\mathrm{r}}\right)$ for smaller,medium and larger fragments is plotted against concentration of GM.

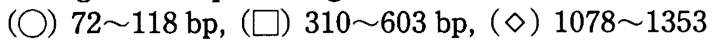
bp.
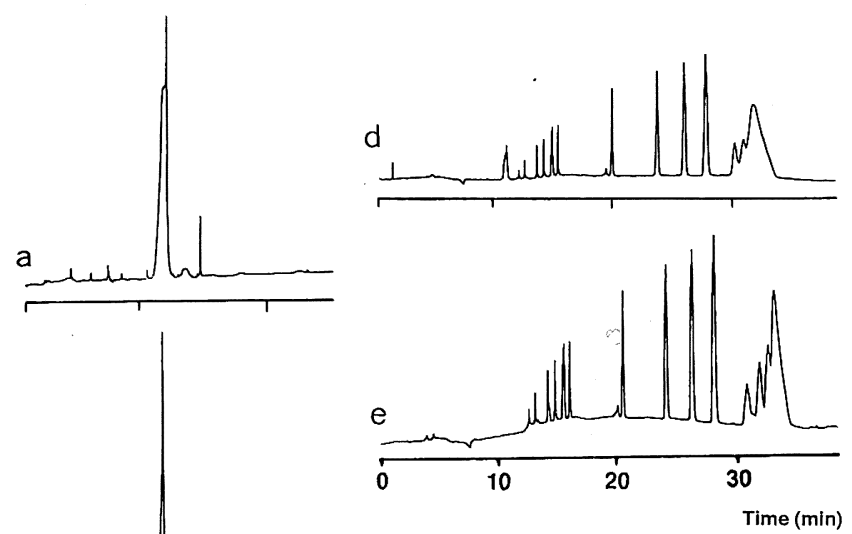

b

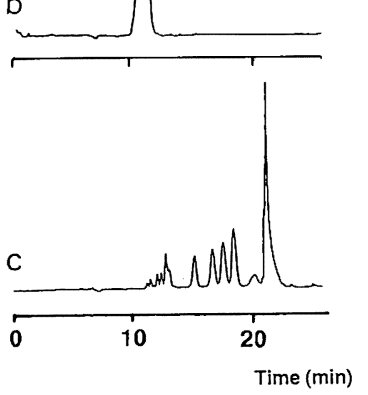

Fig. 7 Effect of average molecular weight of glucomannan on separation of restriction DNA fragments. (a) $27 \mathrm{~K}$ (enzyme-hydrolyzed), (b) $54 \mathrm{~K}$ (enzyme-hydrolyzed), (c) $328 \mathrm{~K}$ (prepared from young tuber), (d) $1300 \mathrm{~K}$, (e) $2000 \mathrm{~K}$.

Conditions

Capillary: (a) $\sim(e) \quad 0.25 \%(\mathrm{w} / \mathrm{w})$ glucomannan in $70 \mathrm{mM}$ Tris- $\mathrm{HCl}$ (pH 8.2), 14 mM EDTA.

Sample: Hae III digest of $\Phi \times 174$ DNA (11 fragments) and Hind III digest of $\lambda$ DNA (8 fragments: 125 $23130 \mathrm{bp}$ )

All other conditions as in Fig. 1. 
持つフラグメントでは, グルコマンナン溶液の濃度の増加と共に 分離度は向上している. 一方, 1078 1353 bp の大きなフラグメ ントでは， $0.25 \%$ を最高に，逆に溶液の濃度の増加と共に分離度 は低下している，これは用いる溶液の濃度によって，形成される 網目の大きさが異なる結果, 分離対象となるフラグメントの大き さが制限されるためと考えられる.すなわち，分離したいフラグ メントの大きさにしたがって，溶液の濃度を適切に調整すること が重要であり, グルコマンナンに限らず他の多糖にも同様のこと が言えると考えられる.

3.6.2 分子量と分離度の関係 : 酵素により低分子化を行った 分子量 2.7 万および 5.4 万，生子(きご)より調製した分子量 32.8 万, 食品用の分子量 130 万および 200 万の各グルコマンナ ンを用いて，それぞれ $0.25 \%$ 溶液を調製し，グルコマンナンの 分子量が分離に与える影響について検討した. エレクトロフェロ グラムを図 7 に示す.

分子量 2.7 万および 5.4 万( $\mathrm{a}, \mathrm{b})$ では，少し肩が見られるがピ ークは 1 本であり, DNA フラグメントは分離しなかった. 分子 量 32.8 万(c)では, $1300 \mathrm{bp}$ 位までのフラグメントの分離はかな り改善されたが，それ以上のフラグメントではほとんど分離して いないのがわかる．分子量 130 万(d)では， 32.8 万で分離してい なかった $6000 \mathrm{bp}$ 以上のフラグメントの相互分離が始まり, 分子 量 200 万ではさらに分離が改善されている.

各グルコマンナンにおける DNA フラグメントの分子量と移動 度の関係を図 8 示す.グルコマンナンの分子量が大きくなるに つれて, DNA フラグメントの移動度は减少し，より大きなフラ グメントほどその傾向が顥著であることがわかる．また，図 9 にグルコマンナンの分子量と三つの分子量範囲に分けた DNA フ ラグメントの分離度の関係を示す.この場合も図 6 と同様, 最 も分離が良かった分子量での分離度を 1 として, 相対分離度で 比較してある. 図から明らかなように，72〜118 bp の小さなフ ラグメントと1078～ 1353 bp の大きなフラグメントでは，グルコ

$\left(\times 10^{-4}\right)$

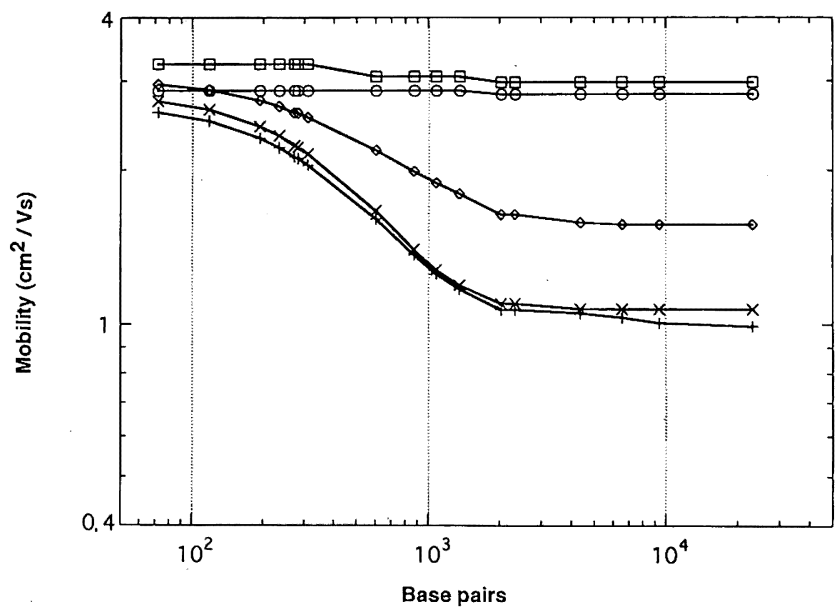

Fig. 8 Effect of average molecular weight of glucomannan on mobility of restriction DNA fragments.

Logarithm of mobility of restriction DNA fragments in Fig. 7 is plotted against size of them.

(○) $27 \mathrm{~K},(\square) 54 \mathrm{~K},(\diamond) 328 \mathrm{~K},(\times) 1300 \mathrm{~K},(+)$ $2000 \mathrm{~K}$.
マンナンの分子量の増加と共に分離度は改善されている. しか し, 分子量 130 万と 200 万では両者の分離度に大きな差は認め られない. 一方, 6557〜9416 bp のかなり大きなフラグメントで は，分子量 130 万から200万にかけて分離度は顕著に改善され ている.すなわち, 分離対象となるフラグメントが大きいほど， 用いるグルコマンナンの分子量を大きくすることが分離度を改善 するのに効果的であり，逆に小さなフラグメントを対象とする場 合はより小さな分子量のものを用いた方が効果的であると考えら れる.

一例として分子量 2.7 万のグルコマンナンを用いた場合の $\mathrm{p}(\mathrm{dT})_{15}$ および $\mathrm{p}(\mathrm{dA})_{40-60}$ のエレクトロフェログラムを図 10に 示す. $\mathrm{p}(\mathrm{dA})_{40-60}$ では移動時間とピーク数は直線関係にあり, 1 塩基ごとに分離されているのがわかる，一方，分子量 200 万の グルコマンナンでは，キャピラリー内に注入可能な $1 \%$ まで濃

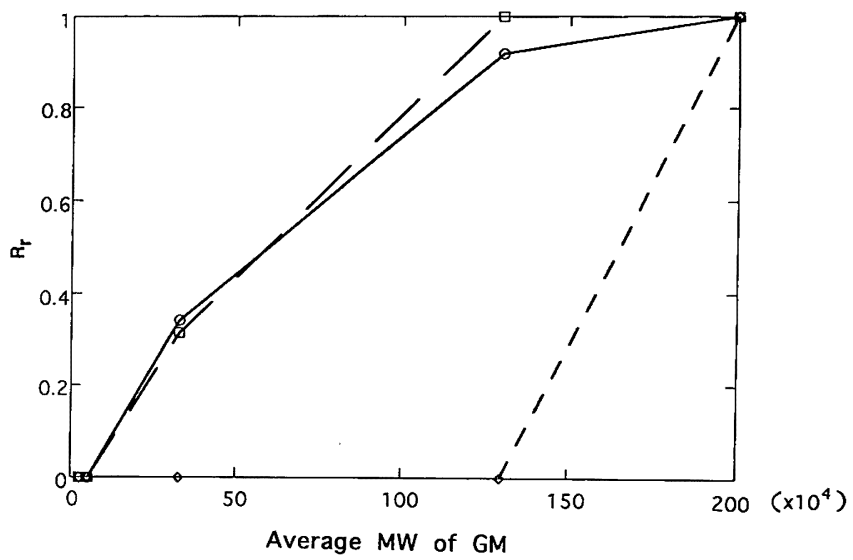

Fig. 9 Effect of average molecular weight of glucomannan (GM) on resolution of restriction DNA fragments. Relative resolution $\left(R_{\mathrm{r}}\right)$ for smaller, larger and very farger fragments is plotted against average molecular weight of GM.

(O) $72 \sim 118 \mathrm{bp}$, ( $\square) 1078 \sim 1353 \mathrm{bp},(\diamond) 6557 \sim$ 9416 bp.
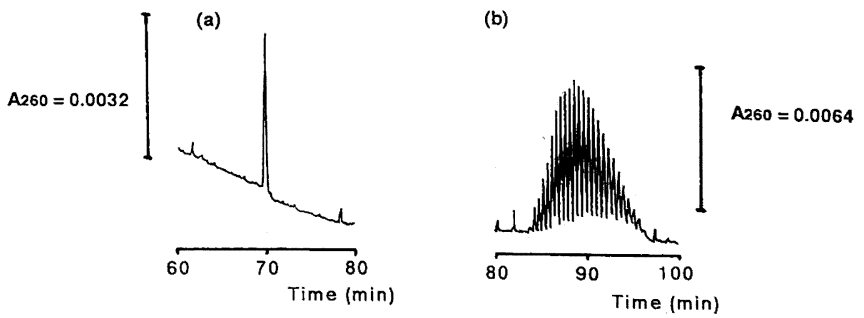

Fig. 10 Separation of $p(d T)_{15}$ and $p(d A)_{40-60}$ using enzyme-hydrolyzed glucomannan.

Conditions

Capillary: J \& W DB-WAX $100 \mu \mathrm{m}$ I.D. $\times 100 \mathrm{~cm} /$ effective length $80 \mathrm{~cm}, 3 \%(\mathrm{w} / \mathrm{w})$ glucomannan $\left(M_{\mathrm{w}} 27\right.$

$\mathrm{K}$ ) in $70 \mathrm{mM}$ Tris- $\mathrm{HCl}$ (pH 8.2), $14 \mathrm{mM}$ EDTA. Injection: $10 \mathrm{kV} 5 \mathrm{~s}$

Run: $10 \mathrm{kV}$

Detection: $260 \mathrm{~nm}$

Sample: (a) $\mathrm{p}(\mathrm{dT})_{15} 0.06 \mathrm{AU}$, (b) $\mathrm{p}(\mathrm{dA})_{40-60} 0.5 \mathrm{AU}$

Instrument: JASCO CE-800 


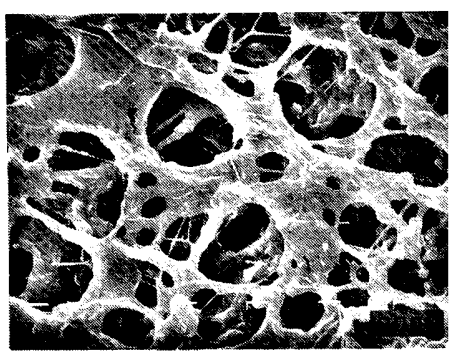

(A)

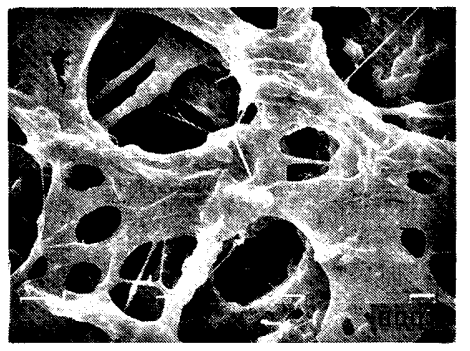

$10 \mu \mathrm{m}$

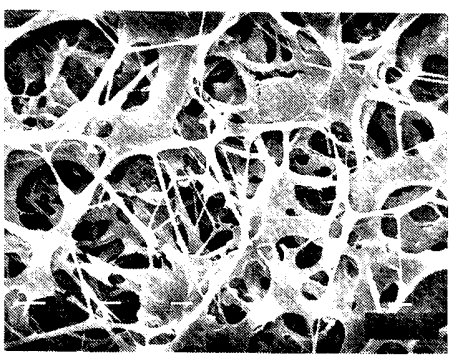

(B)

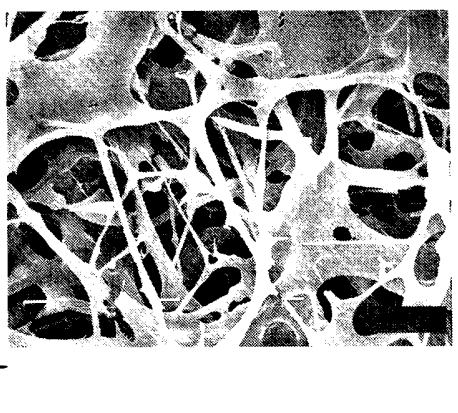

Fig. 11 Scanning electron micrograph of glucomannan. Glucomannan solution $(0.25 \%$, w/w) was lyophilized. (A) $M_{\mathrm{W}} 1300 \mathrm{~K}$ (prepared from old tuber),(B) $M_{\mathrm{W}} 350 \mathrm{~K}$ (prepared from young tuber).

度を高めても, $\mathrm{p}(\mathrm{dA})_{40-60}$ の 1 塩基ことの分離は不可能であっ た.

次に，図 11 に分子量 35 万と 130 万のグルコマンナン蓉液 (0.25\%) を凍結乾燥後走査型電子顕微鏡 $(\mathrm{SEM})$ 観察した写真 を示す．両方の写真で網目の形成が確認できるが, 130 万のむの がより大きな網目を形成しているのがわかる．恐らくキャピラリ 一内でむ SEM 写真に観られるような網目の形成が起こっている むのと推察される. 今回, 一連の SEM 観察の結果, $0.25 \%$ 濃 度でグルコマンナンと同じように大きな網目が確認されたのは, カラクトマンナンであった、キャピラリー内で移動する大きな DNA フラグメントは，このような大きな網目で，はしごくぐり 的に分離されていくむのと推察される.この場合, 移動するフラ グメントに対する抵抗力は水分子の衝突よりも, 主として網目を 形成しているグルコマンナンの鎖（マトリックス）の临突によっ て決まるため，その衝撃に対して十分耐えうる重さ(分子量）と 網目の強度を兼ね備えていることが，高い分離度を達成するため の要件と考えられる.

3.6.3 形成される網目の安定性 : 1 度キャビラリー内に注入 した $0.25 \%$ ボリマー溶液を, 再注入しないで綝り返し分析に使用 し, 分子ふるい添加物としての安定性について検討した. その結 果, 他の多糖と比較してグルコマンナンでは分析回数が増加して も, DNA フラグメントの移動時間, 分離度の変化は小さく, 分 子ふるい添加物としての安定性が確認できた. 移動時間から試料 の分子量を决定するような敩密な分析を行うには，毎回溶液を注
入し直す必要があった. しかし，1回あたり30〜40 分で測定が 終了する試料のパターン解析程度であれば, 1 度の注入で 10 回 前後の使用が可能なことがわかった.

\subsection{PCR 産物分析への適用}

アルツハイマー病患者の脳に沈着するアミロイド $\boldsymbol{\beta}$ タンパク 質 $(\mathrm{A} \boldsymbol{\beta}$ むしくは $\beta / \mathrm{A} 4)$ は，アミロイド前駆体タンパク質(APP) に由来し，特に脳神経においてはアミノ酸 695 個からなる APP(APP695) が主に発現している ${ }^{19)}$. ヒト脳 cDNA ライブラ リーから APP695をコードする cDNA クローンを単離し, 以下 の 4 種類の領域 (塩基配列 1789-2121; $333 \mathrm{bp}$, 塩基配列 $1870-2121 ; 252 \mathrm{bp}$, 塩基配列 1913-2121; $209 \mathrm{bp}$, 塩基配列 $1945-2121 ; 177$ bp) の cDNA を PCR(Polymerase Chain Reaction の略）で増幅した. 各 PCR 産物の分析結果を図 12k示す. 各 PCR 産物は，標準 DNA フラグメントの移動時間から推定さ れる分子量とよく一致した．中た，従来のスラブゲル電気泳動法 と比較して, 分離度は約 10 倍, 分析時間は約 $1 / 3$, 試料導入量 から求めた検出感度は約 1000 倍になることが確認できた.

\section{8 分離条件の最適化}

3.5および3.6で得られた結果をもとに，分離対象物質の分子 量に対するグルコマンナンの分子量と溶液濃度の最適条件を検討 した．結果の一例を図 13に示す。図 7 の条件(分子量 200 万， 濃度 $0.25 \%$ ）では，数千 bp といったかなり大きな DNA フラグ メントの分離は不十分であった．これは溶液の濃度が高いため, キャピラリー内で形成される網目が小さくなっており，数千 bp 

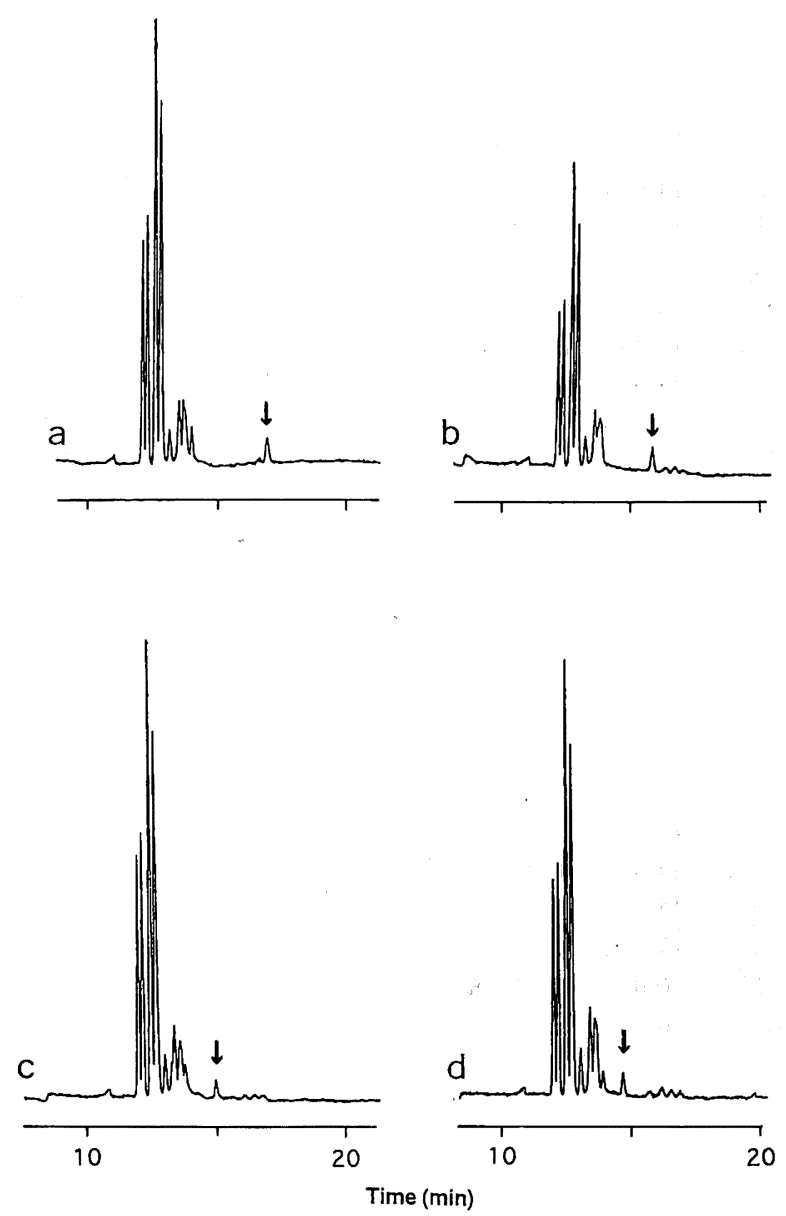

Fig. 12 Electropherogram of polymerase chain reaction (PCR) products.

Each PCR products derived from APP (amyloid protein precursor) cDNA was directly analyzed. $(\downarrow)$ PCR product.
(a) $333 \mathrm{bp}$ (sequence $1789-2121$ ), (b) $252 \mathrm{bp}$ (se- quence $1870-2121$ ), (c) $209 \mathrm{bp}$ (sequence 1913 -2121), (d) $177 \mathrm{bp}$ (sequence 1945-2121).

Conditions

Capillary: J \& W DB-WAX $100 \mu \mathrm{m}$ I.D. $\times 50 \mathrm{~cm} /$ effective length $25 \mathrm{~cm}, 0.25 \%(\mathrm{w} / \mathrm{w})$ glucomannan $\left(M_{\mathrm{W}}\right.$ $350 \mathrm{~K})$ in $70 \mathrm{mM}$ Tris- $\mathrm{HCl}(\mathrm{pH} 8.2), 14 \mathrm{mM}$ EDTA.

Instrument: ABI Model $270 \mathrm{~A}$

All other conditions as in Fig. 1.

のフラグメントの分離度を低下させていると考えられる．溶液濃 度を $0.2 \%$ に低下させた結果，図 13に示すように小さなフラグメ ントの分離度は少し悪くなっているが，逆にかなり大きなフラグ メントの分離度は改善されたことがわかる。この場合, 僅か 0.05\%の濃度差ではあるが，グルコマンナンの分子量が大きいた けに分離に大きく影響することがわかった．このように分離対象 物質ごとにグルコマンナンの分子量および容液濃度を詳細に検討 した結果，図 14に示すマップが最適条件として作成できた。

\section{9 繰り返し分析の再現性}

同一グルコマンナン溶液を用いて, 繰り返し分析における再現 性および測定日を変えての再現性を調べた．また，別々に調製し

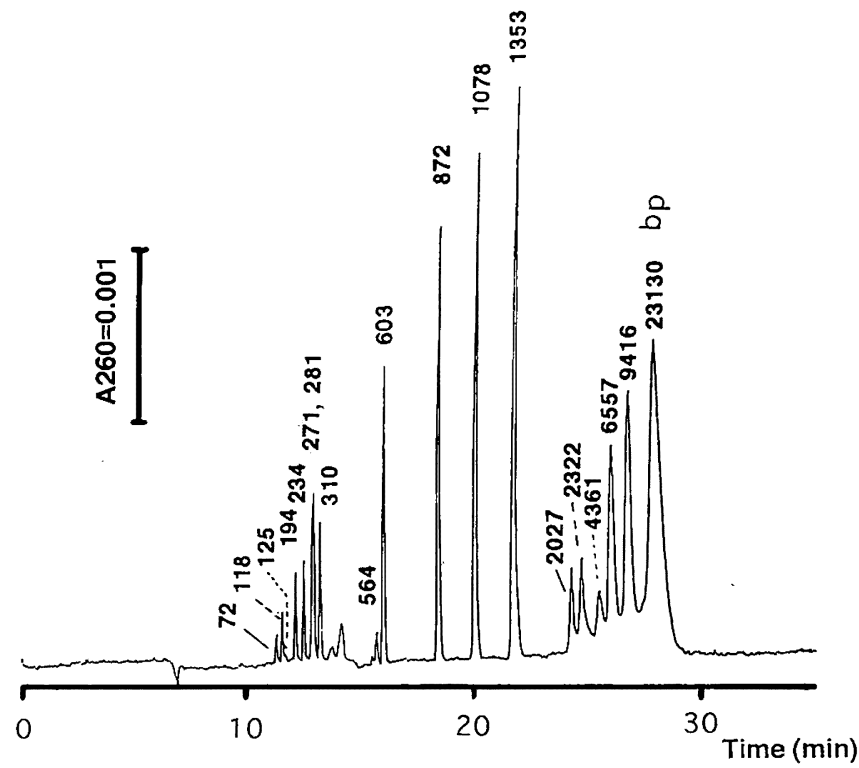

Fig. 13 Separation of restriction DNA fragments under opitimized conditions.

Conditions

Capillary: $0.2 \%(\mathrm{w} / \mathrm{w})$ glucomannan $\left(M_{\mathrm{W}} 2000 \mathrm{~K}\right)$ in 70 $\mathrm{mM}$ Tris- $\mathrm{HCl}$ (pH 8.2), 14 mM EDTA.

Sample: Hae III digest of $\Phi \times 174$ DNA and Hind III digest of $\lambda$ DNA

All other conditions as in Fig. 1.

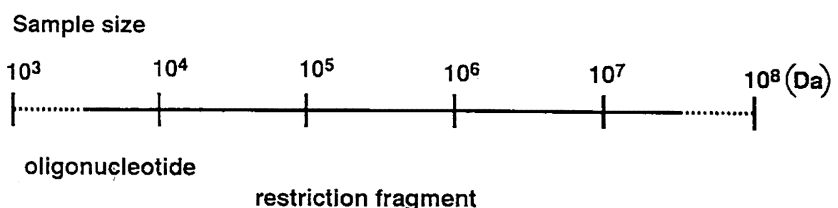

plasmid, phage DNA

$3-5 \% 27 k$ GM

$0.25 \% 350 \mathrm{k} \mathrm{GM}$

$0.25 \% 1300 \mathrm{k} \mathrm{GM}$

$0.2 \% 2000 \mathrm{k} \mathrm{GM}$

Fig. 14 Diagrammatic representation of optimum conditions of glucomannan-added capillary for separation of biological macromolecules.

た溶液を用いて, 溶液間の変動を調ぺた。結果を表 1 ～ 3 に示 す. いずれにおいても変動係数(C.V.) は $2 \%$ 以内であり,ルー チン分析，自動分析に十分適用できるむのと判断する．比較のた め使用した市販のゲル充填キャピラリーでは，C.V.は $5 \%$ 以上 と悪く，満足のいく再現性を得ることは困難であった．ポリマー 溶液を用いる方法は，分析ごとに溶液交換を行う必要があるた め, マニュアル分析では操作が煩雑であることは否定できない. しかし，その再現性の高さから，今後分析法の主流になるものと 考えられ，優れた自動分析装置の開発が期待される. 
Table 1 Reproducibility on migration time of restriction DNA fragments by refilling capillary with stock solution of glucomannan

\begin{tabular}{|c|c|c|c|c|c|c|c|c|c|c|c|}
\hline \multirow{2}{*}{$\begin{array}{c}\text { Expt. } \\
\text { No. }\end{array}$} & \multicolumn{11}{|c|}{ Migration time (min) / Hae III digest of $\Phi \times 174$ DNA (11 Fragments) } \\
\hline & $72 \mathrm{bp}$ & $118 \mathrm{bp}$ & $194 \mathrm{bp}$ & $234 \mathrm{bp}$ & $271 \mathrm{bp}$ & $281 \mathrm{bp}$ & $310 \mathrm{bp}$ & $603 \mathrm{bp}$ & $872 \mathrm{bp}$ & $1078 \mathrm{bp}$ & $1353 \mathrm{bp}$ \\
\hline 1 & 11.625 & 12.092 & 13.083 & 13.642 & 14.267 & 14.367 & 14.825 & 19.258 & 22.933 & 25.100 & 26.833 \\
\hline 2 & 11.422 & 11.908 & 12.875 & 13.425 & 14.033 & 14.133 & 14.583 & 18.925 & 22.542 & 24.692 & 26.450 \\
\hline 3 & 11.358 & 11.825 & 12.792 & 13.350 & 13.900 & 14.042 & 14.500 & 18.850 & 22.483 & 24.642 & 26.400 \\
\hline 4 & 11.408 & 11.867 & 12.833 & 13.383 & 13.900 & 14.067 & 14.533 & 18.858 & 22.483 & 24.642 & 26.433 \\
\hline 5 & 11.350 & 11.817 & 12.755 & 13.325 & 13.850 & 14.000 & 14.467 & 18.792 & 22.450 & 24.625 & 26.458 \\
\hline $\bar{x}$ & 11.437 & 11.902 & 12.872 & 13.425 & 13.990 & 14.122 & 14.582 & 18.937 & 22.578 & 24.740 & 26.515 \\
\hline S.D. & 0.112 & 0.112 & 0.124 & 0.127 & 0.169 & 0.145 & 0.143 & 0.186 & 0.201 & 0.203 & 0.179 \\
\hline C.V. \% & 0.978 & 0.944 & 0.966 & 0.946 & 1.20 & 1.02 & 0.978 & 0.981 & 0.891 & 0.819 & 0.676 \\
\hline
\end{tabular}

All conditions as in Fig. 3.

Table 2 Daily variation on migration time of restriction DNA fragments by filling capillary with stock solution of glucomannan

\begin{tabular}{cccccccccccc} 
Day & \multicolumn{8}{c}{ Migration time(min)/Hae II digest of $\Phi$ x 174 DNA(11 Fragments) } \\
& $72 \mathrm{bp}$ & $118 \mathrm{bp}$ & $194 \mathrm{bp}$ & $234 \mathrm{bp}$ & $271 \mathrm{bp}$ & $281 \mathrm{bp}$ & $310 \mathrm{bp}$ & $603 \mathrm{bp}$ & $872 \mathrm{bp}$ & $1078 \mathrm{bp}$ & $1353 \mathrm{bp}$ \\
\hline 1 & 11.483 & 11.908 & 12.800 & 13.317 & 13.867 & 13.967 & 14.392 & 18.425 & 21.808 & 23.833 & 25.508 \\
2 & 11.325 & 11.775 & 12.708 & 13.242 & 13.833 & 13.925 & 14.358 & 18.558 & 22.067 & 24.142 & 25.833 \\
3 & 11.350 & 11.817 & 12.775 & 13.325 & 13.850 & 14.000 & 14.467 & 18.792 & 22.450 & 24.625 & 26.458 \\
$\bar{x}$ & 11.386 & 11.833 & 12.761 & 13.294 & 13.850 & 13.964 & 14.405 & 18.591 & 22.108 & 24.200 & 25.933 \\
S.D. & 0.084 & 0.067 & 0.047 & 0.045 & 0.017 & 0.037 & 0.055 & 0.185 & 0.322 & 0.399 & 0.482 \\
C.V. \% & 0.74 & 0.57 & 0.37 & 0.34 & 0.12 & 0.26 & 0.38 & 0.99 & 1.46 & 1.64 & 1.86
\end{tabular}

All conditions as in Fig. 3.

Table 3 Reproducibility on migration time of restriction DNA fragments by filling capillary with different stock solution of glucomannan

\begin{tabular}{|c|c|c|c|c|c|c|c|c|c|c|c|}
\hline \multirow{2}{*}{$\begin{array}{c}\text { Stock } \\
\text { No. }\end{array}$} & \multicolumn{11}{|c|}{ Migration time (min) /Hae III digest of $\Phi \times 174$ DNA(11 Fragments) } \\
\hline & $72 \mathrm{bp}$ & $118 \mathrm{bp}$ & $194 \mathrm{bp}$ & $234 \mathrm{bp}$ & $271 \mathrm{bp}$ & $281 \mathrm{bp}$ & $310 \mathrm{bp}$ & $603 \mathrm{bp}$ & 872 bp & $1078 \mathrm{bp}$ & $1353 \mathrm{bp}$ \\
\hline 1 & 11.217 & 11.642 & 12.542 & 13.050 & 13.600 & 13.700 & 14.117 & 18.150 & 21.525 & 23.550 & 25.267 \\
\hline 2 & 11.483 & 11.908 & 12.800 & 13.317 & 13.867 & 13.967 & 14.392 & 18.425 & 21.808 & 23.833 & 25.508 \\
\hline S.D. & 0.188 & 0.188 & 0.182 & 0.188 & 0.188 & 0.188 & 0.194 & 0.194 & 0.200 & 0.200 & 0.170 \\
\hline C.V. \% & 1.65 & 1.59 & 1.43 & 1.43 & 1.37 & 1.36 & 1.36 & 1.06 & 0.92 & 0.84 & 0.67 \\
\hline
\end{tabular}

All conditions as in Fig. 3.

\section{4 結 論}

今回, グルコマンナンおよび市販のスラブ電気泳動用試薬を含 む多糖類を，CE 用ポリマー溶液に適用し，比較検討した結果以 下の結論を得た.

(1)分離媒体であるグルコマンナンの分離度に及ぼす因子を検討 した結果，濃度と分子量の影響が大きいことがわかった．特に， 分離対象物質の分子量がオリゴスクレオチドのようにかなり小さ い場合，また数千 bp の DNA フラグメントのようにかなり大き い場合には，分離度は溶液の濃度よりむしろグルコマンナンの分 子量に大きく依存することが明らかになった。

(2)分離対象物質の分子量に応じて，グルコマンナンの分子量お よび濃度を検討した結果, 最適条件を決定できた。

(3)同一条件で制限酵素消化 DNA フラグメントの分離を行った 結果, グルコマンナンで最も高い分離度が得られた。これは主
に,グルコマソナンの分岐の少ない直鎖構造と大きな分子量によ って安定な網目が形成されるためと考えられる.

(4)グルコマンナン溶液は, 保存安定性, 分析の再現性にすぐれ, $\mathrm{CE}$ 用ポリマー溶液に不可欠な特徵を持っていることが確認でき た.

本研究を行うにあたり, グルコマンナンの入手並びに精製のご 指導を賜りました清水化学株式会社の深津佳也, 清水寿夫の両氏 にお礼を申し上げます。

本研究の内容の一部は, 第 1 回クロマトグラフィーシンポジ ウム「最新の分離メディアと応用」(1994 年 6 月, 京都) で発表 済み。

1) R. A. Mathies, X. C. Huang, Nature, 359, 167 (1992).

2) H. Kambara, S. Takahashi, Nature, 361, 565(1993).

3) B. L. Karger, Nature, 339, 641(1989). 
4) A. S. Cohen, D. R. Najarian, A. Paulus, A. Guttman, J. A. Smith, B. L. Karger, Proc. Natl. Acad. Sci. USA, 85, 9660 (1988).

5) A. Guttman, A. S. Cohen, D. N. Heiger, B. L. Karger, Anal. Chem., 62, $137(1990)$.

6) M. Zhu, D. L. Hanse, S. Burd, F. Gannon, J. Chromatogr., 480, 311(1989).

7) H. E. Schwartz, K. Ulfelder, F. J. Sunzeri, M. P. Busch, R. G. Brownlee, J. Chromatogr., 559, 267(1991).

8) K. Ulfelder, H. E. Schwartz, J. H. Hall, F. J. Sunzeri, Anal. Biochem., 200, 260(1992).

9）真鍋 敬, ぶんせき，234, 467(1994).

10）中村洋，佐野 明，太田隆文，鈴木政雄，235, 554(1994).

11) M. Yamaguchi, T. Yamamoto, T. Tomoda, Y. Motozato,
Bull. Chem. Soc. Jpn., 66, 639(1993).

12) 山口正人, 飯泉太郎, 山本哲郎, 本里義明, 日化, 1993, 837.

13）山口正人, 山本哲郎, 脇田正明, 本里義明, 日化, 1993, 1335.

14) T. Izumi, M. Yamaguchi, K. Yoneda, T. Isobe, T. Okuyama, J. Chromatogr., 652, 41(1993).

15）泉 友則, 山口正人, 礒辺俊明, 奥山典生, 篠田友孝, Chromatography, 14, 79(1993).

16) Bio Industry, 12, 53(1995).

17）沖増 哲, “こんにゃくの科学”, 渓水社(1993) pp. 134〜 139.

18) T. Kato, T. Katsuki, A. Takahashi, Macromolecules, 17, 1726(1984).

19) D. J. Selkoe, Neuron, 6, 487 (1991).

\title{
Resolution of Biological Macromolecules by Capillary Electrophoresis Using
} Konjac Glucomannan as Macromolecule-Sieving Additive

\author{
Masato Yamaguchi*, Tomonori IzUMI ${ }^{\dagger}$, Toshiaki IsOBE ${ }^{\dagger}$ and Tsuneo OKUYAMA ${ }^{\text {tH }}$ \\ Central Laboratories, Kurita Water Industries Ltd.; 7-1 Wakamiya, Morinosato, \\ Atugi-shi 243-01 Japan \\ †Department of Chemistry, Faculty of Science, Tokyo Metropolitan University; \\ 1-1 Minami-Ohsawa, Hachiouji-shi 192-03 Japan \\ "Present adress; Department of Molecular and Pathological Biochemistry, School of Medicine, \\ Yamagata University; 2-2-2 Iida-Nishi, Yamagata-shi 990-23 Japan \\ +tPresent adress; Department of Dental Biotechnology and Bioengineering, Kanagawa \\ Dental College; 82 Inaoka-cho, Yokosuka-shi 238 Japan
}

Several polysaccharides were employed as a molecule-sieving additive for the separation of biological macromolecules in capillary electrophoresis (CE). Especially, glucomannan with an average molecular weight of $3 \times 10^{5} \sim 2 \times 10^{6} \mathrm{Da}$, prepared from the crude polysaccharide of Amorphophallus konjac, exhibited good resolution and reproducibility on separation of biological macromolecules. Under optimized conditions, restriction DNA fragments were separated into each size. Based on its migration time, estimation of fragment size of the several restriction digests was performed without internal standards. And an enzyme-hydrolysed glucomannan with low molecular weight was also applied to separate oligonucleotides in CE. Highly reproducible separation was achieved by refilling the capillay with fresh glucomannan solution in each analytical cycle.

We concluded that the glucomannan is a good alternative to the conventional sieving additives for $\mathrm{CE}$, such as polyacrylamide and hydroxypropylmethylcellulose, and this method would be applied to molecular cloning of a gene, separation and analysis of DNA fragments generated by restriction enzyme digestion or produced by polymerase chain reaction. 